\title{
Agonistic and mating behaviour of the endemic lizard Trachylepis atlantica from the Fernando de Noronha archipelago, Brazil
}

\author{
VINICIUS PERON DE OLIVEIRA GASPAROTTO ${ }^{1,2}$, SERENA NAJARA MIGLIORE ${ }^{3,4^{*}}$, RAFAEL PINHEIRO ${ }^{5}$, \\ RICARDO AUGUSTO DIAS ${ }^{1}$ \& SELMA MARIA DE ALMEIDA-SANTOS ${ }^{3,4}$
}

\author{
${ }^{1}$ Departamento de Medicina Veterinária Preventiva e Saúde Animal, Faculdade de Medicina Veterinária e Zootecnia, \\ Universidade de São Paulo, Avenida Orlando Marques de Paiva, 87, 05508-270, São Paulo, SP, Brazil \\ ${ }^{2}$ Instituto Brasileiro para Medicina da Conservação - TRÍADE, Rua Silveira Lobo, 32, 52061-030, Recife, PE, Brazil \\ ${ }^{3}$ Setor de Anatomia, Departamento de Cirurgia, Faculdade de Medicina Veterinária e Zootecnia, Universidade de São Paulo, \\ Avenida Orlando Marques de Paiva, 87, 05508-270, São Paulo, SP, Brazil \\ ${ }^{4}$ Laboratório de Ecologia e Evolução, Instituto Butantan, Avenida Vital Brazil, 1500, 05503-900, São Paulo, SP, Brazil \\ ${ }^{5}$ Centro Golfinho Rotador, Rua Eurico Cavalcante de Albuquerque, 5, Vila do Boldró, 53990-000, Fernando de Noronha, PE, Brazil \\ *Corresponding author e-mail:serena.migliore@esib.butantan.gov.br
}

\begin{abstract}
The skink Trachylepis atlantica is endemic to the Fernando de Noronha archipelago. Although this species is abundant in the archipelago, it is increasingly threatened by invasive species, predation, and anthropic interference. However, little is known about its natural history. Here we report on territory use, male-male combat, and mating behaviour of freeranging $T$. atlantica. During the dry season, we observed two bouts of male combat and two copulations, which suggests some mating seasonality. In male combat, T. atlantica displays ritualised agonistic behaviour with escalated aggressiveness that include-i) visualisation, approaching or following, ii) visual display, iii) bite and body confrontation, and iv) dominance. Adult males were always alert to invaders within their territories. After combat, resident males showed scars on their heads resulting from agonistic encounters. During the two copulations, we observed courtship, immobilisation, and mating.
\end{abstract}

\section{INTRODUCTION}

$S_{a}^{k}$ inks of the genus Trachylepis occur mainly in Africa, but single representative, the Noronha skink Trachylepis atlantica (Schmidt, 1945), occurs in the New World, on the Fernando de Noronha archipelago, off the north-eastern coast of Brazil (Travassos, 1946; Mausfeld et al., 2002; Carranza \& Arnold, 2003). The ancestors of $T$. atlantica are suggested to have reached the archipelago about nine million years ago by natural transoceanic dispersal of rafting vegetation (Mausfeld et al., 2002; Carranza \& Arnold, 2003). The Noronha skink is an opportunistic generalist, feeding on insects, plant material, and even nectar from the flowers of the mulungu tree (Erythrina velutina) (Sazima et al., 2005; Rocha et al., 2009). Although the species has not yet been classified by the International Union for the Conservation of Nature, it was recently reclassified locally as 'threatened' (unpublished data, State Environment Agency - AEMA, 2017). Trachylepis atlantica is abundant in the Noronha archipelago but many aspects of its biology remain unknown and, despite the increasing knowledge of lizard behaviour, studies on the agonistic behaviour of skinks are scarce (Torr \& Shine, 1994). Some species show elaborate social behaviours and complex interactions associated with reproduction (SánchezHernández et al., 2012). Here, we provide the first report of male competition and mating behaviour of free-ranging $T$. atlantica.

\section{MATERIALS \& METHODS}

The Fernando de Noronha archipelago (area $=18.2 \mathrm{~km}^{2}$ ) is located $350 \mathrm{~km}$ off the north-eastern coast of Brazil and comprises 21 islands and islets (Carleton \& Olson, 1999; Almeida, 1995). Temperature is constantly warm throughout the year $\left(\sim 27{ }^{\circ} \mathrm{C}\right)$. Rainfall is highly seasonal, with the rainy season occurring from March to August and the dry season from September to February (Almeida, 1955). Field observations were made on the main and secondary islands in February, April, October, November, and December of 2015, 2016, and 2018 (Fig. 1). Observations were made from 10:00 to $15: 00 \mathrm{~h}$, when lizards are most active (Rocha et al., 2009), inside a capture-mark-resight parcel (main island) and in point transects on the main island and on four smaller islands Rata, Meio, Morro da Viúva, and Chapéu (for population density methodology see Gasparotto, 2019). The first author filmed the social interactions using a Nikon Coolpix P610 digital camera; care was taken to keep a distance that would not disturb the lizards. We recorded the date, time, location, and duration of each combat and copulation (Fig. 1; Table 1). We considered 'territory defence' any behaviour that caused escape or avoidance of rival individuals so that an area became of exclusive use to the resident male (Martins, 1994). We defined combat as any aggressive act involving physical contact (e.g., biting, wrestling) that may cause injury (Martins, 1994). Because of the evident male-biased sexual size dimorphism (Rocha et al., 2009), it is possible to identify the sex of adult individuals without capturing 


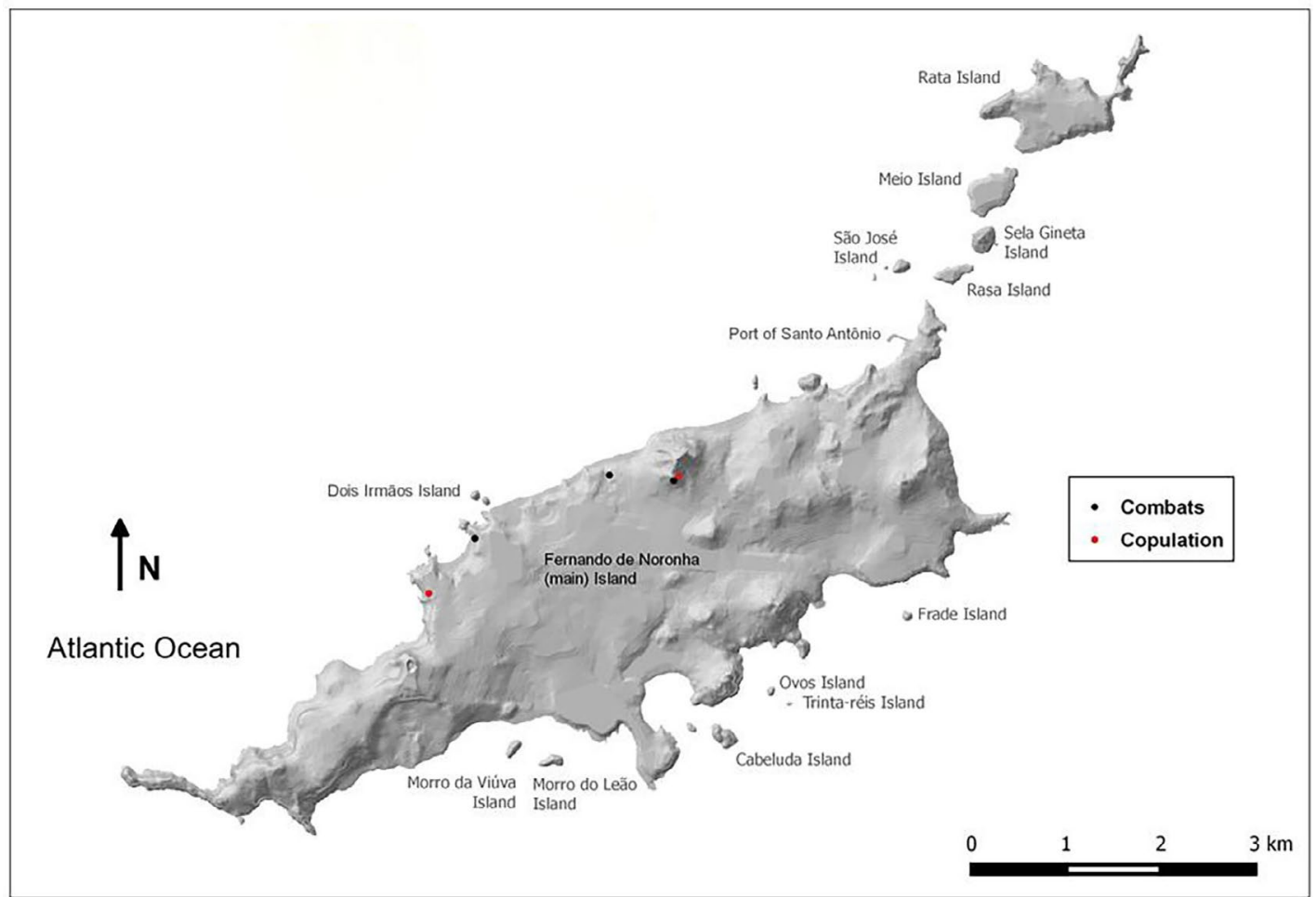

Figure 1. Map of the Fernando de Noronha archipelago indicating the locations of behavioural observations

Table 1. Metadata for observations made on the social interactions of the Noronha skink, Trachylepis atlantica, recorded in the Fernando de Noronha archipelago

\begin{tabular}{|cccccccccc|}
\hline Record & Interaction & Date & Site & $\begin{array}{c}\text { Interaction duration } \\
(\mathbf{m i n})\end{array}$ & Start time & End time & Season & Record \\
\hline 1 & Mating & $02 / 23 / 2015$ & Piquinho & 1 & $10: 53$ & $10: 54$ & Dry & Photo \\
2 & Male-male combat & $02 / 23 / 2015$ & Boldró & 15 & $14: 24$ & $14: 39$ & Dry & Photo and video \\
3 & Territory defence & $02 / 26 / 2015$ & Boldró & $<1$ & $10: 01$ & $10: 01$ & Dry & No media \\
4 & Territory defence & $11 / 25 / 2015$ & Golfinho & $<1$ & $11: 40$ & $11: 40$ & Dry & No media \\
5 & Territory defence & $02 / 06 / 2016$ & Tejuaçu & $<1$ & $9: 14$ & $9: 14$ & Dry & No media \\
6 & Territory defence & $02 / 06 / 2016$ & Piquinho & 6 & $14: 47$ & $14: 53$ & Dry & Photo and video \\
7 & Courtship & $02 / 06 / 2016$ & Piquinho & $<1$ & $14: 52$ & $14: 52$ & Dry & Video \\
8 & Territory defence & $02 / 10 / 2016$ & Tejuaçu & $<1$ & $10: 32$ & $10: 32$ & Dry & No media \\
9 & Male-male combat & $02 / 11 / 2016$ & Sancho & 3 & $15: 16$ & $15: 19$ & Dry & Photo and video \\
10 & Territory defence & $02 / 17 / 2016$ & Americano & $<1$ & $9: 40$ & $9: 40$ & Dry & No media \\
11 & Territory defence & $02 / 19 / 2016$ & Americano & $<1$ & $9: 55$ & $9: 55$ & Dry & No media \\
12 & Territory defence & $11 / 02 / 2016$ & Leão & $<1$ & $11: 58$ & $11: 58$ & Dry & No media \\
13 & Mating & $12 / 29 / 2018$ & Golfinho & 2 & $9: 10$ & $9: 12$ & Dry & Video \\
\hline
\end{tabular}

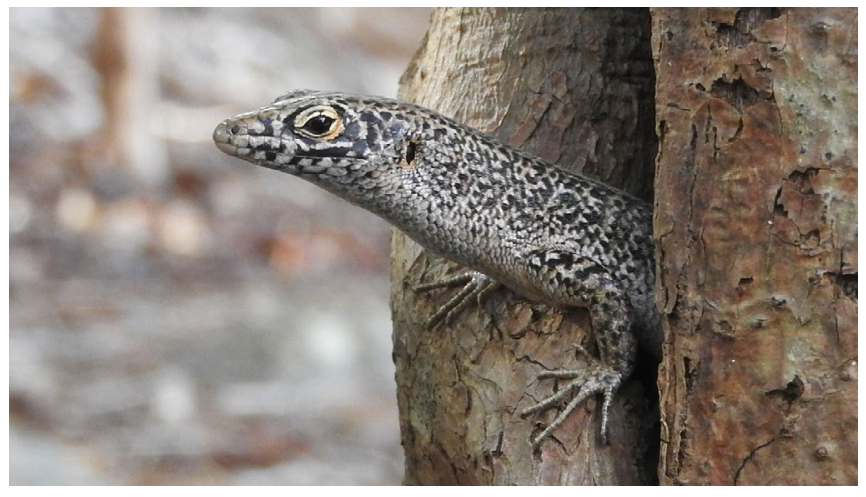

Figure 2. An adult male Trachylepis atlantica using a hole in a tree as a shelter (November 25th, 2015, at Golfinho, Fernando de Noronha archipelago). The male was alert to the approach of other conspecifics. them. The study was conducted under the approval of the Instituto Chico Mendes de Conservação da Biodiversidade (Brazilian Ministry of Environment, permit number 41682-1) and the Animal Ethics Committee of the School of Veterinary Medicine of the University of São Paulo (1827250515)

\section{RESULTS}

\section{Agonistic behaviour}

We identified the following behavioural repertoire during interactions between males.

Alert - The resident male is alert to possible invaders in his territory. When a male enters an occupied territory, the resident male runs towards the invader, chasing and expelling him from the territory. 


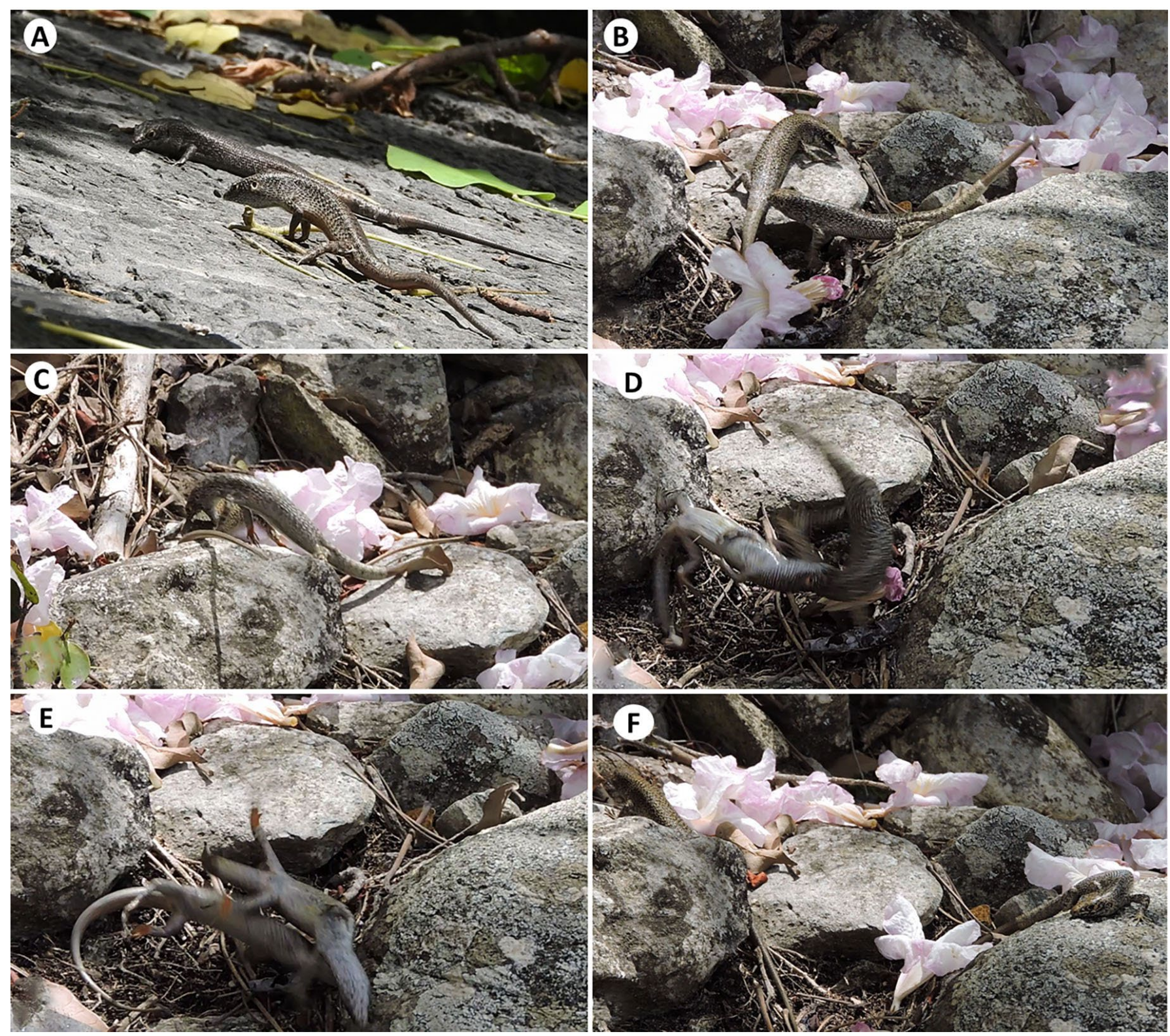

Figure 3. Male combat behaviour of Trachylepis atlantica observed on February 23rd, 2015, at Boldró, Fernando de Noronha archipelago - A. Two adult males positioned parallel to each other while compressing the body laterally and lifting the four limbs, B. One of the males opens his mouth to intimidate and eventually bite his opponent, C. - E. Body confrontation and attacks directed at the head and tail of the rival, followed by body rotation, $\mathbf{F}$. The combat ends with the pursuing male expelling the rival from the territory
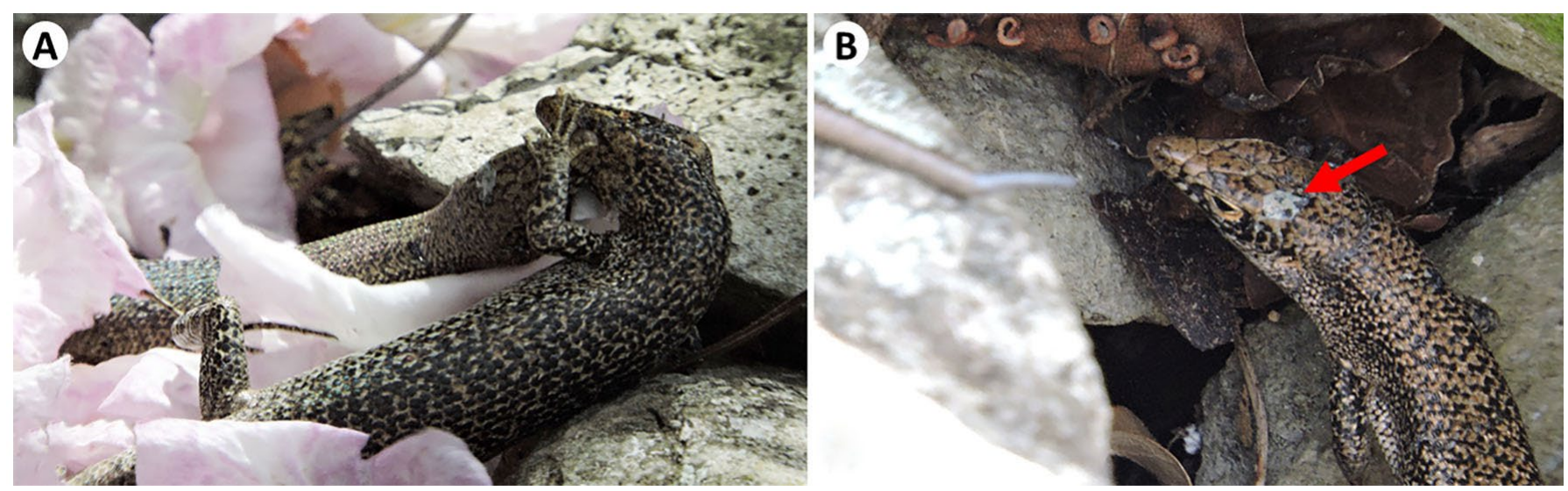

Figure 4. Male combat of the Trachylepis atlantica (February 23rd, 2015, Boldró, Fernando de Noronha archipelago) - A. A male biting his rival's head, making it impossible for the opponent to open his mouth, B. A male with a head injury (red arrow) after the combat 

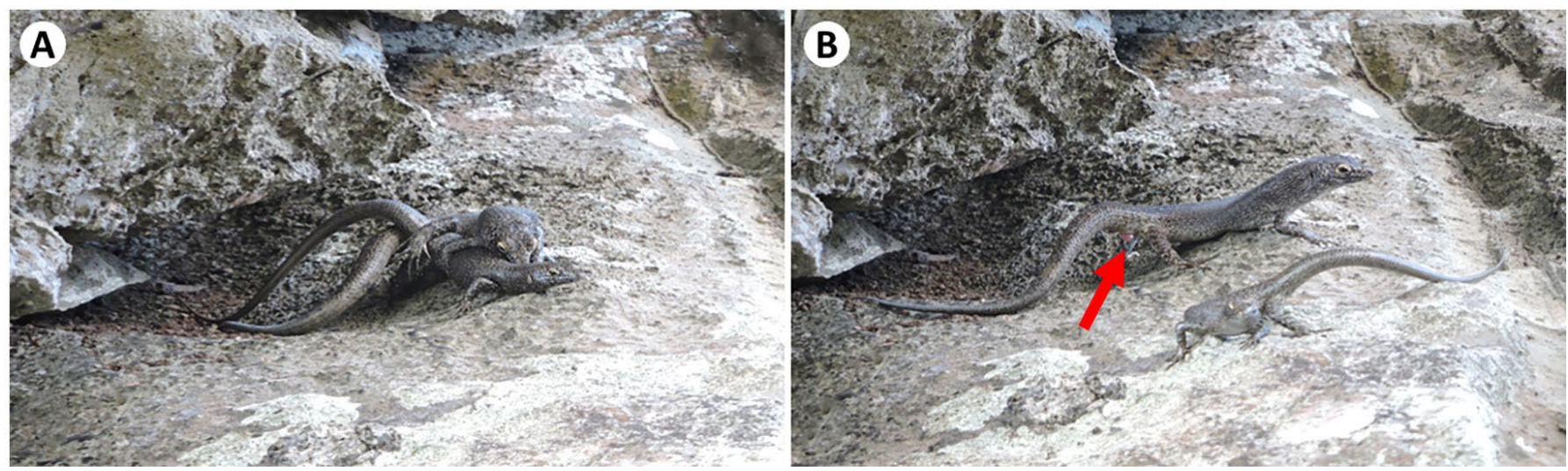

Figure 5. Mating behaviour of Trachylepis atlantica (February 23rd, 2015, Piquinho, Fernando de Noronha archipelago) - A. The male bites and holds the female while inserting his hemipenis into her cloaca, B. Post-mating, note that the male's hemipenis (red arrow) remains everted

Body (visual) display - This consists of visual contact and body alignment. Males position themselves parallel to each other and switch positions frequently, directing their heads parallel to the opponent's tail.

Slow-motion walk - Lizards stand on tiptoes, arch their bodies upwards, walk in slow motion arching their necks. In some cases, the opponent keeps its venter and head on the substrate.

Bite and body confrontation - This consists of bites directed at the tail, cloacal region, neck, and head. As the combat continues, the males become breathless and decrease the frequency of attacks.

Dominance - The submissive male flees the territory, followed by the dominant male, which continues to attack.

To view some details of these agonistic behaviours watch our video (BHS video, 2021).

\section{Description of the observed combats}

All observations of agonistic interactions were made only on the main island during the dry season in February and December (Table 1). Seven resident males showed territorial defence behaviour. The resident males were alert most of the time. Male territories were usually associated with shelters and feeding sites. Locations with many rocks or tree trunks provide safe hiding places and often had greater numbers of lizards (Fig. 2). On two occasions (23rd February 2015 and 11th February 2016), the invading male remained in the territory even after the resident male approached; consequently, the lizards engaged in combat. These agonistic interactions had already started when we first detected them (Figs. 3 and 4). The males moved around while slightly arching their bodies (slow motion walk), inflating the gular region, and compressing the trunk laterally (Fig. $3 \mathrm{~A}$ ). These behaviours proceeded for a while, with the males often switching positions and positioning themselves parallel to each other. Shortly before the attack, the individuals opened and closed their mouths. Next, the lizards moved slowly towards the opponent with short and abrupt movements. All individuals performed slow and side-to-side undulations of the tail end to direct the opponent's attack to that region (Fig. 3B, C). Individual males often exhibit tail injury or breakage and in one agonistic interaction, a male ripped and ingested the tip of his rival's tail (VPOG, pers. obs.). The attacker bit the opponent while rotating its own body (Fig. 3C, D). Throughout the combat, both rival males launched sequential attacks that alternated with body displays. Fighting males had scars on their heads (Fig. 4A, B). In the third observation (6th February 2016), we noticed only body displays (without attacks) and that both individuals were panting, suggesting that the agonistic interaction was ending or that the resident male was just defending the boundaries of his territory. Tongue-flicking occurred a few times throughout this behaviour. In all combats, we identified the same behavioural repertoire described above.

\section{Mating behaviour}

We identified the following behavioural repertoire during male-female reproductive interactions.

Courtship - The male approaches the female performing rapid and frequent head bobs.

Immobilisation - The male bites the female's neck or limb and holds her body with his hindlimb.

Mating - The male inserts the hemipenis into the female's cloaca.

\section{Description of the observed mating}

We observed two copulations on the main island during the dry season (Table 1). When a female entered an occupied territory, the resident male approached and started to court her. Females moved through the territories of several males. The first copulation occurred on 23rd February 2015 (late dry season). The male immobilised the female by biting her on the neck and holding her body with his right hindlimb. Then, the male positioned himself so that the female's tail was lifted, thus allowing the insertion of the hemipenis into the female's cloaca (Fig. 5A). Although copulation was underway when we began our observations, the male still took 30 seconds to release the female and retract his hemipenis. After copulation, the male stayed close to the female, following her for some time. The second copulation occurred on 29th December 2018 (mid-dry season). The male chased the female, started the courtship and bit her near the left forelimb to immobilise her. While the male tried to insert the hemipenis into the female's cloaca, another male approached, causing the first male to move away holding the 
female by her neck. Next, the male immobilised the female by biting her on the left forelimb and then rubbed his left hindlimb on hers. After a few seconds, the female lifted her tail, allowing the male to insert his hemipenis into her cloaca. The mating was recorded for only 12 seconds, but it lasted approximately two minutes.

\section{DISCUSSION}

We report for the first time male-male agonistic interaction and mating in T. atlantica. Because male combats occurred in the same season as mating, we infer that male-male agonistic interactions in $T$. atlantica are related to territory defence and probably access to females. Indeed, vitellogenic females have also been observed in the same period as mating (Rocha et al., 2009).

Territoriality is often correlated with access to females (Koenig, 2017), and combat ability strongly predicts species fitness (Cooper, 1999). Male body size is related to better territories (i.e., greater availability of resources); thus, the larger the male, the better its territory (Olsson \& Madsen, 1995; Sacchi et al., 2009). These observations may explain the male-biased sexual size dimorphism recorded in $T$. atlantica (Travassos, 1946; Rocha et al., 2009). Territory defence is favoured when the payoffs, such as access to females and territorial exclusivity, are higher than the costs of expelling potential competitors (Stamps, 1994). Experienced male individuals are more likely to succeed in agonistic encounters with other males, resulting in greater access to females (Kim \& Zuk, 2000). Besides the three agonistic interactions observed, resident males also attacked other males that entered their territories during courtship. Occasionally, male and female individuals were seen close to each other (VPOG, pers. obs.), suggesting that male and female territories overlap or that females move through the male territories.

Agonistic interactions are common in reptiles and usually associated with the reproductive season (Brattstrom, 1974; Shine, 1978; Gillingham et al., 1983; Denardo \& Licht, 1993; Almeida-Santos et al., 1998). Agonistic behaviour seems uncommon in skinks (Cooper \& Vitt, 1987a, b; Cooper, 1999; Chapple, 2003; Langkilde et al., 2003) but common in varanids (Murphy \& Mitchell, 1974; Thompson \& Withers, 1997), helodermatids (Beck \& Ramiréz-Bautista, 1991), iguanids and agamids (Moehn, 1974; Rand \& Rand, 1976), and even in the tuatara (Gans et al., 1984). Agonistic interactions usually exhibit varying degrees of ritualisation, which may culminate in high energy costs and potentially fatal injuries (Langkilde et al., 2005).

Several male $T$. atlantica had mutilated or regenerated tails. These observations corroborate previous descriptions that lizards may autotomise only the tip of the tail when facing a predator (Cooper \& Smith, 2009). The "economy of tail autotomy" may be advantageous because it allows the rest of the tail to be autotomised in later events (Cooper \& Smith, 2009). Another proposed advantage is that the tail portion left intact functions as a lateral counterbalance that keeps the individual stability during flight (Ballinger et al., 1979). However, frequent tail bites may contribute to a decrease in territorial dominance, as observed in the phrynosomatid lizard
Uta stansburiana. Dominance decreases after individuals lose their tails in agonistic interactions (Fox \& Rostker, 1982; Fox et al., 1990). Many lizard species also use tail undulation during agonistic interactions as an antipredatory tactic and in social interactions to direct the rival's attention to the tail (Murphy \& Mitchell, 1974; Cooper, 2001). Making the tail visible deflects the attack away from the body, thus avoiding injury to the head and vital organs (Fox et al., 1990). However, tail undulation has also been described as submissive and evasive behaviour in subordinate individuals of some species, such as Tropidurus semitaeniatus and Chalcides viridanus (Sánchez-Hernández et al., 2012; Bruinjé et al., 2019). We suggest that the Noronha skink uses tail undulation to divert the rival's attention and direct attacks to the tail.

The aggressive behaviour of $T$. atlantica is similar to that described for other skinks (Done \& Heatwole, 1977; Torr \& Shine, 1994; Torr \& Shine,1996; Sánchez-Hernández et al., 2012). In Trachylepis, agonistic interactions have been observed in T. margaritifera (Wymann \& Whiting, 2002) and $T$. sechellensis (Brooke, 1983). In T. margaritifera, male combat seems to be associated with the maintenance of territories during the reproductive season (Wymann \& Whiting, 2002).

Carpenter (1963) observed that iguanids and agamids that inhabit areas where sight is of limited importance exhibit less elaborate behaviours and more discrete displays. As skinks are less territorial and many are fossorial, they are believed to lack social display (Stamps, 1977a). Evans (1961) suggested that the limited repertoire of agonistic and courtship behaviours in skinks derives from greater dependence on olfactory stimuli than visual signals for interspecific recognition. In several lizard species, pheromones that mediate agonistic interactions, mate attraction, and territory demarcation are released from femoral pores (Cooper, 1994; Bruinjé et al., 2020). Although we observed some tongueflicking, we observed no femoral or cloacal pores, suggesting that male $T$. atlantica rely heavily on visual signals during agonistic behaviour, similar to that observed in the skink Carlia jarnoldae (Langkilde et al., 2003).

Lateral compression of the body is performed when individuals are close to each other and often precedes bites. This behaviour has also been described in the skinks C. viridanus and Lampropholis guichenoti (Torr \& Shine, 1994; Sánchez-Hernández et al., 2012). Unlike several lizard species that commonly perform head bobs and tongue flicks during male-male combat and courtship (Langkilde et al., 2003; Coelho et al., 2018; Bruinjé et al., 2019), a male Noronha skink performs these behaviours most of the time that a female is in its territory. Slow-motion behaviour also occurs in the skink Carlia jarnoldae, mainly during courtship (Langkilde et al., 2003). Torr and Shine (1994) suggested that the slow-motion behaviour in the skink $L$. guichenoti is an assertion display in agonistic interactions. Biting has also been reported during male-male combat in several lizard genus, such as Anolis (Vanhooydonck et al., 2005) and Crotaphytus (Husak et al., 2006). Biting, chasing, and approaching are considered intimidating postures, performed mainly by dominant males (Bruinjé et al., 2019). In T. atlantica, many individuals showed head scars and regenerated tails, possibly caused by bites during male combat. 
The mating behaviour of $T$. atlantica is similar to that described for several skinks (e.g., Fitch, 1954; Evans, 1961) and unrelated lizards (Barreto-Lima \& Sousa, 2006; SánchezHernández et al., 2012; Migliore et al., 2014). Prolonged neck bites are likely to be advantageous and suggestive of mate guarding in other lizard species, including skinks (Bull, 2000). In conclusion, our observations on the agonistic behaviour of $T$. atlantica contribute to the understanding of ritualised combat behaviour and the use of visual signals during agonistic interactions in the Scincidae. We suggest that the high density of lizards in the Fernando de Noronha archipelago, the absence of femoral pores, and the scarce tongue flicking during agonistic interactions corroborate the greater use of visual than chemical signals. The occurrence of male combat and mating in the same season (dry season) suggests that such behaviours are associated with the reproductive season of this species.

\section{ACKNOWLEDGMENTS}

We thank the administrations of the State District of Fernando de Noronha, Instituto Chico Mendes de Conservação da Biodiversidade (ICMBio), Parque Nacional Marinho de Fernando de Noronha, Área de Proteção Ambiental de Fernando de Noronha-Rocas-São Pedro e São Paulo, Centro Nacional de Pesquisa e Conservação de Répteis e Anfíbios (RAN/ICMBio), and Fire Department of Fernando de Noronha for allowing this study to be conducted. We also thank Mauro Teixeira Jr. for valuable suggestions during the manuscript preparation. We are thankful to The Rufford Foundation (grant number 18890-1), Coordenação de Aperfeiçoamento de Pessoal de Nível Superior (PVE Project number 88881.065000/2014-1), Fundação de Amparo à Pesquisa do Estado de São Paulo (project number, 2016/16433-1) for the financial support and the Conselho Nacional de Desenvolvimento Científico e Tecnológico (CNPq) for research fellowships (\#310357/2018-7). This study was partially financed by the Coordenação de Aperfeiçoamento de Pessoal de Nível Superior - Brasil (CAPES) - Finance Code 001.

\section{REFERENCES}

Agência Estadual de Meio Ambiente [AEMA] (2017). Lista Estadual de Répteis Ameaçados - Pernambuco, Governo do Estado de Pernambuco. http://www.cprh.pe.gov.br/ home/42872;57450;10;3351;17946.asp. Accessed 10th December 2018.

Almeida-Santos, S.M., Schmidt de Aguiar, L.F. \& Balestrin, R.L. (1998). Micrurus frontalis (coral snake). Male combat. Herpetological Review 29: 242.

Almeida, F.F.M. (1955). Geologia e petrologia do arquipélago de Fernando de Noronha. Rio de Janeiro: SERGRAF do IBGEpp. 181 pp.

Ballinger, R.E., Nietfeldt, J.W. \& Krupa, J.J. (1979). An experimental analysis of the role of the tail in attaining high running speed in Cnemidophorus sexlineatus (Reptilia: Squamata: Lacertilia). Herpetologica 35: 114116.

Barreto-Lima, A.F. \& Sousa, B.M. de (2006). Court and copulation behaviors of Enyalius perditus Jackson, 1978 (Squamata, Leiosauridae) in captivity conditions. Revista Brasileira de Zoociências 8: 193-197.

Beck, D.D. \& Ramiréz-Bautista, A. (1991). Combat behavior of the beaded lizard, Heloderma $h$. horridum, in Jalisco, Mexico. Journal of Herpetology 25: 481-484.

BHS video (2021). Male combat in the skink Trachylepis atlantica. https://youtu.be/z5ygl-f0xkk

Brattstrom, B.H. (1974). The evolution of reptilian social behaviour. American Zoologist 14: 35-49.

Brooke, M. L., \& Houston, D. C. (1983). The biology and biomass of the skinks Mabuya sechellensis and Mabuya wrightii on Cousin Island, Seychelles (Reptilia: Scincidae). Journal of Zoology 200: 179-195.

Bruinjé, A.C., Coelho, F.E.A., Paiva, T.M.A. \& Costa, G.C. (2019). Aggression, color signaling, and performance of the male color morphs of a Brazilian lizard (Tropidurus semitaeniatus). Behavioral Ecology and Sociobiology 73: 72.

Bruinjé, A.C., Coelho, F.E., Maggi, B.S. \& Costa, G.C. (2020). Chemical signalling behaviour in intrasexual communication of lizards lacking femoral pores. Ethology 126: $772-779$.

Bull, C.M. (2000). Monogamy in lizards. Behavioural Processes 51: 7-20.

Carleton, M.D. \& Olson, S.L. (1999). Amerigo Vespucci and the rat of Fernando de Noronha: a new genus and species of Rodentia (Muridae: Sigmodontinae) from a volcanic island off Brazil's continental shelf. American Museum Novitates 3256: 1-59.

Carpenter, C.C. (1963). Patterns of behavior in three forms of the fringe-toed lizards (Uma-Iguanidae). Copeia 1963: 406-412.

Carranza, S. \& Arnold, E.N. (2003). Investigating the origin of transoceanic distributions: Mtdna shows Mabuya lizards (Reptilia, Scincidae) crossed the Atlantic twice. Systematics and Biodiversity 1: 275-282.

Chapple, D.G. (2003). Ecology, life-history, and behavior in the Australian Scincid genus Egernia, with comments on the evolution of complex sociality in lizards. Herpetological Monographs 17: 145-180.

Coelho, F.E.A., Bruinje, A.C. \& Costa, G.C. (2018). Ethogram with the description of a new behavioral display for the striped lava lizard, Tropidurus semitaeniatus. South American Journal of Herpetology 13: 96-101.

Cooper, W.E. (1994). Chemical discrimination by tongueflicking in lizards: a review with hypotheses on its origin and its ecological and phylogenetic relationships. Journal of Chemical Ecology 20: 439-487.

Cooper, W.E. (1999). Tradeoffs between courtship, fighting, and antipredatory behavior by a lizard, Eumeces laticeps. Behavioral Ecology and Sociobiology 47: 54-59.

Cooper, W.E. (2001). Multiple roles of tail display by the curlytailed lizard Leiocephalus carinatus: Pursuit deterrent and deflective roles of a social signal. Ethology 107: 11371149.

Cooper, W.E. \& Vitt, L.J. (1987a). Deferred agonistic behavior in a long-lived scincid lizard Eumeces laticeps - Field and laboratory data on the roles of body size and residence in agonistic strategy. Oecologia 72: 321-326. 
Cooper, W.E. \& Vitt, L.J. (1987b). Intraspecific and interspecific aggression in lizards of the scincid genus Eumeces Chemical-Detection of Conspecific Sexual Competitors. Herpetologica 43: 7-14.

Cooper, W.E. \& Smith, C.S. (2009). Costs and economy of autotomy for tail movement and running speed in the skink Trachylepis maculilabris. Canadian Journal of Zoology-Revue Canadienne De Zoologie 87: 400-406.

Denardo, D.F. \& Licht, P. (1993). Effects of corticosterone on social-behavior of male lizards. Hormones and Behavior 27: 184-199.

Done, B.S. \& Heatwole, H. (1977). Social-behavior of some Australian skinks. Copeia 1977: 419-430.

Evans, L.T. (1961). Structure as related to behavior in the organization of populations in reptiles. In Vertebrate Speciation. A University of Texas Symposium, 148-178 pp., W.F. Blair (Ed.). Austin: University of Texas Press.

Fitch, H.S. (1954). Life history and ecology of the five-lined skink, Eumeces fasciatus. Publications of the Museum of Natural History University of Kansas 8: 1-156.

Fox, S.F. \& Rostker, M.A. (1982). Social cost of tail loss in Uta stansburiana. Science 218: 692-693.

Fox, S.F., Heger, N.A. \& Delay, L.S. (1990). Social cost of tail loss in Uta stansburiana - Lizard tails as status-signaling badges. Animal Behaviour 39: 549-554.

Gans, C., Gillingham, J.C. \& Clark, D.L. (1984). Courtship, mating and male combat in tuatara, Sphenodon punctatus. Journal of Herpetology 18: 194-197.

Gasparotto, Vinícius Peron de Oliveira (2019). Conservação do Mabuia (Trachylepis atlantica, Schmidt, 1945) no Arquipélago de Fernando de Noronha - PE: reprodução, densidade populacional e avaliação sanitária. Tese (Doutorado em Ciencias) - Universidade de São Paulo. São Paulo. pp. 109.

Gillingham, J.C., Carpenter, C.C. \& Murphy, J.B. (1983). Courtship, male combat and dominance in the western diamondback rattlesnake, Crotalus atrox. Journal of Herpetology 17: 265-270.

Guedes, T., Guedes, A. \& de Almeida-Santos, S.M. (2019). Male-male fighting, dominance, and mating in Epicrates assisi (Serpentes: Boidae) in captivity. Phyllomedusa 18: 131-135.

Husak, J.F., Lappin, A.K., Fox, S.F. \& Lemos-Espinal, J.A. (2006). Bite-force performance predicts dominance in male venerable collared lizards (Crotaphytus antiquus). Copeia 2006: 301-306.

Kim, T. \& Zuk, M. (2000). The effects of age and previous experience on social rank in female red junglefowl, Gallus gallus spadiceus. Animal Behaviour 60: 239-244.

Koenig, M. (2017). The relationship between sex and territorial behavior in the San Cristóbal lava lizard (Microlophus bivittatus). Thesis, College of St. Benedict/ St. John's University, St Joseph, USA. 24 pp.

Langkilde, T., Schwarzkopf, L. \& Alford, R. (2003). An ethogram for adult male rainbow skinks, Carlia jarnoldae. Herpetological Journal 13: 141-148.

Langkilde, T., Lance, V.A. \& Shine, R. (2005). Ecological consequences of agonistic interactions in lizards. Ecology 86: 1650-1659.
Martins, E.P. (1994). Phylogenetic perspectives on the evolution of lizard territoriality. In Lizard Ecology: Historical and Experimental Perspectives, 117-144 pp. Vitt L.J. \& Pianka E.R. (Eds.). Princeton: Princeton University Press.

Mausfeld, P., Schmitz, A., Böhme, W., Misof, B., Vrcibradic, D. \& Rocha, C.F.D. (2002). Phylogenetic affinities of Mabuya atlantica Schmidt, 1945, endemic to the Atlantic Ocean Archipelago of Fernando de Noronha (Brazil): Necessity of partitioning the genus Mabuya Fitzinger, 1826 (Scincidae: Lygosominae). Zoologischer Anzeiger 241: 281-293.

Migliore, S.N., Braz, H.B. \& Almeida-Santos, S.M. (2014). Reproductive aspects of two Enyalius lizards from the Atlantic forest in Southeastern Brazil. Herpetology Notes 7: 273-276.

Moehn, L.D. (1974). The effect of quality of light on agonistic behaviour of iguanid and agamid lizards. Journal of Herpetology 8: 175-183.

Murphy, J.B. \& Mitchell, L.A. (1974). Ritualized combat behaviour of the pygmy muglia monitor lizard, Varanus gilleni (Sauria: Varanidae). Herpetologica 30: 90-97.

Olsson, M. \& Madsen, T. (1995). Female choice on male quantitative traits in lizards - Why is it so rare. Behavioral Ecology and Sociobiology 36: 179-184.

Rand, W.M. \& Rand, A.S. (1976). Agonistic behavior in nesting iguanas - stochastic analysis of dispute settlement dominated by minimization of energy-cost. Zeitschrift Fur Tierpsychologie 40: 279-299.

Rocha, C.F.D., Vrcibradic, D., Menezes, V.A. \& Ariani, C.V. (2009). Ecology and natural history of the easternmost native lizard species in south america, Trachylepis atlantica (Scincidae), from the Fernando de Noronha Archipelago, Brazil. Journal of Herpetology 43: 450-459.

Sacchi, R., Pupin, F., Gentilli, A., Rubolini, D., Scali, S., Fasola, M. \& Galeotti, P. (2009). Male-male combats in a polymorphic lizard: residency and size, but not color, affect fighting rules and contest outcome. Aggressive Behavior 35: 274-283.

Sánchez-Hernández, P., Ramírez-Pinilla, M.P. \& Molina-Borja, M. (2012). Agonistic and courtship behaviour patterns in the skink Chalcides viridanus (Fam. Scincidae) from Tenerife. Acta Ethologica 15: 65-71.

Sazima, I., Sazima, C. \& Sazima, M. (2005). Little dragons prefer flowers to maidens: a lizard that laps nectar and pollinates trees. Biota Neotropica 5: 1-8.

Shine, R. (1978). Sexual size dimorphism and male combat in snakes. Oecologia 33: 269-277.

Stamps, J. (1977a). Social behavior and spacing patterns in lizards. In Biology of the Reptilia. Vol. 7. Ecology and Behaviour A, 265-334 pp. C. Gans and D.W. Tinkle (Eds.). London: Academic Press.

Stamps, J.A. (1977b). The relationship between resource competition, risk, and aggression in a tropical territorial lizard. Ecology 58: 349-358.

Stamps, J. (1994). Territorial behavior - testing the assumptions. Advances in the Study of Behavior 23: 173-232.

Sullivan, B.K. \& Kwiatkowski, M.A. (2007). Courtship displays in anurans and lizards: theoretical and empirical contributions to our understanding of costs and selection 
on males due to female choice. Functional Ecology 21: 666-675.

Thompson, G.G. \& Withers, P.C. (1997). Comparative morphology of western Australian varanid lizards (Squamata: Varanidae). Journal of Morphology 233: 127-152.

Torr, G.A. \& Shine, R. (1994). An ethogram for the small scincid lizard Lampropholis guichenoti. Amphibia-Reptilia 15: 21-34.

Torr, G. A., \& Shine, R. (1996). Patterns of dominance in the small scincid lizard Lampropholis guichenoti. Journal of Herpetology, 230-237.
Travassos, H. (1946). Estudo da variação de Mabuya punctata (Gray, 1839). Boletim do Museu Nacional Rio de Janeiro Zoologia 60: 1-46.

Vanhooydonck, B., Herrel, A.Y., Van Damme, R. \& Irschick, D.J. (2005). Does dewlap size predict male bite performance in Jamaican Anolis lizards? Functional Ecology 19: 38-42. Wymann, M.N. \& Whiting, M.J. (2002). Foraging ecology of rainbow skinks (Mabuya margaritifer) in Southern Africa. Copeia 2002: 943-957.

Accepted: 29 July 2021 